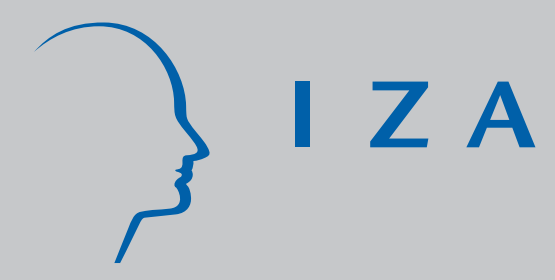

IZA DP No. 3729

Human Capital Externalities with

Monopsonistic Competition

Leo Kaas

September 2008 


\title{
Human Capital Externalities with Monopsonistic Competition
}

\author{
Leo Kaas \\ University of Konstanz \\ and IZA
}
Discussion Paper No. 3729
September 2008

\author{
IZA \\ P.O. Box 7240 \\ 53072 Bonn \\ Germany \\ Phone: +49-228-3894-0 \\ Fax: +49-228-3894-180 \\ E-mail: iza@iza.org
}

\begin{abstract}
Any opinions expressed here are those of the author(s) and not those of IZA. Research published in this series may include views on policy, but the institute itself takes no institutional policy positions.

The Institute for the Study of Labor (IZA) in Bonn is a local and virtual international research center and a place of communication between science, politics and business. IZA is an independent nonprofit organization supported by Deutsche Post World Net. The center is associated with the University of Bonn and offers a stimulating research environment through its international network, workshops and conferences, data service, project support, research visits and doctoral program. IZA engages in (i) original and internationally competitive research in all fields of labor economics, (ii) development of policy concepts, and (iii) dissemination of research results and concepts to the interested public.
\end{abstract}

IZA Discussion Papers often represent preliminary work and are circulated to encourage discussion. Citation of such a paper should account for its provisional character. A revised version may be available directly from the author. 
IZA Discussion Paper No. 3729

September 2008

\section{ABSTRACT}

\section{Human Capital Externalities with Monopsonistic Competition *}

This paper provides a novel microeconomic foundation for pecuniary human capital externalities in a labor market model of monopsonistic competition. Multiple equilibria arise because of a strategic complementarity in investment decisions.

JEL Classification: D43, J24

Keywords: externalities, human capital, multiple equilibria

Corresponding author:

Leo Kaas

Department of Economics

University of Konstanz

78457 Konstanz

Germany

E-mail: leo.kaas@uni-konstanz.de

\footnotetext{
* I am grateful to Stefan Zink for helpful comments.
} 


\section{Introduction}

Many theoretical and empirical contributions emphasize the importance of human capital externalities for growth patterns and underdevelopment traps. In a seminal paper, Acemoglu (1996) provides a microeconomic foundation for such externalities which are not "technological" as in the early growth models of Lucas (1988) or Azariadis and Drazen (1990) but "pecuniary" in the sense that human capital investment affects factor prices in a growth-enhancing way. More investment in human capital triggers a surge in physical capital investment which, through labor search frictions, benefits all workers and raises the skill premium. A similar externality exists with respect to physical capital, but if the labor market is frictionless, all these pecuniary externalities disappear. Moreover, Acemoglu's argument strongly rests on technological complementarity between capital and labor.

This paper develops a different channel where pecuniary externalities emerge when the labor market is characterized by another departure from the Walrasian benchmark: monopsonistic competition between employers. To this end, I augment the model of Bhaskar and To (1999) by an education choice of workers prior to firms' investment. A pecuniary human capital externality emerges whose mechanism is quite different from Acemoglu's model. When more workers invest in skills, more firms invest in skill-intensive technology. This makes wage competition between these firms more intense, driving skilled wages up, further stimulating incentives to invest in education. As in Acemoglu (2003), an increase in educational attainment raises the skill premium through investment in skill-biased technology. However, the argument does not rely on technological complementarity between capital and labor, and productivity of skilled workers does not increase with more investment; instead the skilled wage increases because of intensified competition.

Another result of this paper is equilibrium multiplicity: the strategic complementarity between investment decisions implies that an equilibrium with positive investment always co-exists with a (stable) no-investment equilibrium. Thus, underdevelopment traps can occur as a result of coordination failure. 


\section{The model}

Consider a regional labor market which is a circle of unit length in the spirit of Salop (1979) and Bhaskar and To (1999). The region is populated by a uniformly distributed group of workers of mass $M$, each supplying one unit of indivisible labor. Workers can either work in a competitive low-skill labor market at wage $b$, or they can obtain education and work in one of finitely many, symmetrically located "technology firms" employing skilled labor. Education is a 0-1 decision and workers must incur a positive (effort) cost to obtain it. Education costs are uniformly distributed on $[0, C M]$ and are uncorrelated with location. That is, at any circle segment of length $\varepsilon$, mass $m \varepsilon$ of workers has education cost of $C m$ or smaller, for any $m \in[0, M]$.

All educated workers are equally productive at all technology firms and output per worker is denoted $A$. An educated worker living distance $x$ from his employer pays commuting costs $t x$ in order to travel to work. ${ }^{1}$ Workers aim to maximize their income net of the costs of commuting and education. Firms maximize profit net of entry (or capital) costs which are $F>0$ for all technology firms. The strategic interaction between firms and workers is modeled by the following three-stage game.

Stage I: Workers decide whether to obtain education or not.

Stage II: Technology firms enter the labor market and locate symmetrically.

Stage III: Entrant firms $i=1, \ldots, n$ simultaneously announce high-skill wages $w_{i}$. Skilled workers decide to work at the firm where wage income net of commuting costs are largest.

The timing assumption that workers obtain education before technology firms enter reflects the idea that an irreversible education choice has a longer time horizon than an irreversible capital investment. It is also assumed that workers at stage I cannot

\footnotetext{
${ }^{1}$ There is also a non-geographic interpretation of this model where "locations" reflect non-wage job characteristics and workers' preferences over these horizontally differentiated characteristics.
} 
foresee firms' locations at stage II (although they correctly anticipate how many firms enter the labor market). This seems reasonable given that firms are indifferent between all symmetric locations. ${ }^{2}$ Throughout the following analysis, $A$ is large relative to $t$ and $b$ so that all educated workers decide to work for a technology firm rather than working at the low-skill wage $b .^{3}$ It is also assumed that $M$ is so large that not all workers obtain education.

\section{Equilibrium and multiplicity}

I solve the model by backward induction. When $E<M$ workers obtain education and $n$ technology firms enter the market, labor supply to any firm $i$ offering $w_{i}$ when all others offer $w$ is

$$
L\left(w_{i}, w\right)=\left[\frac{1}{n}+\frac{w_{i}-w}{t}\right] E,
$$

provided that $\left|w_{i}-w\right| \leq t / n$. Firm $i$ maximizes $\left(A-w_{i}\right) L\left(w_{i}, w\right)$ which leads to the best response $w_{i}=(A-t / n+w) / 2$ and thus to the symmetric Nash equilibrium where $w_{i}=w=w^{*}=A-t / n$ and where profit of each technology firm is $\pi=E t / n^{2}$.

At stage II, the number of entrants $n$ is the solution to the free-entry condition

$$
\frac{E t}{n^{2}}=F
$$

In the following, I deliberately ignore integer problems and I also ignore the monopsony case $n=1$. At the first stage, a worker with education cost $C m$ obtains education if the expected high-skill income net of expected commuting costs and

\footnotetext{
${ }^{2}$ An alternative assumption giving rise to the same result is that workers are randomly relocated on the circle after obtaining education.

${ }^{3}$ The assumption of a competitive low-skill labor market simplifies the analysis, but similar results (i.e. equilibrium multiplicity and human capital externalities) can also be obtained when there is monopsonistic competition between an endogenous number of low-technology firms.
} 
education costs exceeds the low-skill wage, i.e. ${ }^{4}$

$$
b \leq w^{*}-2 n \int_{0}^{1 /(2 n)} t x d x-C m=A-\frac{5 t}{4 n}-C m .
$$

It follows that mass $E$ of workers obtain education where

$$
C E \geq A-b-\frac{5 t}{4 n}, E \geq 0
$$

with complementary slackness. Figure 1 illustrates the free-entry (capital investment) condition (1) and the education condition (2). It is clear that there are generically either the three equilibria as shown by the intersections of these curves, or only one equilibrium with $E=n=0$. If education and entry costs are not too large, there are three equilibria, one is the no-investment equilibrium at $E=n=0$, and there are two others with positive investment. Of these two, only the one with more education and entry at $\left(n^{*}, E^{*}\right)$ is "stable" in the natural adjustment dynamics (where after a small deviation $E_{0} \neq E^{*}$ workers anticipate that $n_{0}$ firms enter which would trigger $E_{1}$ educated workers, $n_{1}$ firms, $E_{2}$ educated workers and so on, with $\left.E_{t} \rightarrow E^{*}\right)$. The no-investment equilibrium is also stable in the sense that an education investment by a small group of workers is followed by no entry of technology firms since not even a monopsonist would be willing to incur the positive fixed cost to employ these workers.

\section{Inefficiency}

The social planner maximizes total output net of the costs of commuting, education and entry, with respect to $n$ and $E$,

$$
\begin{aligned}
W(n, E) & =2 n E \int_{0}^{1 /(2 n)} A-t x d x+(M-E) b-\int_{0}^{E} C m d m-F n \\
& =M b+E\left[A-b-\frac{t}{4 n}\right]-\frac{C E^{2}}{2}-n F .
\end{aligned}
$$

\footnotetext{
${ }^{4}$ As explained above, each worker anticipates that $n$ firms enter but he does not know the distance $x \in[0,1 /(2 n)]$ to the nearest of these firms which is uniformly distributed with density $2 n d x$.
} 


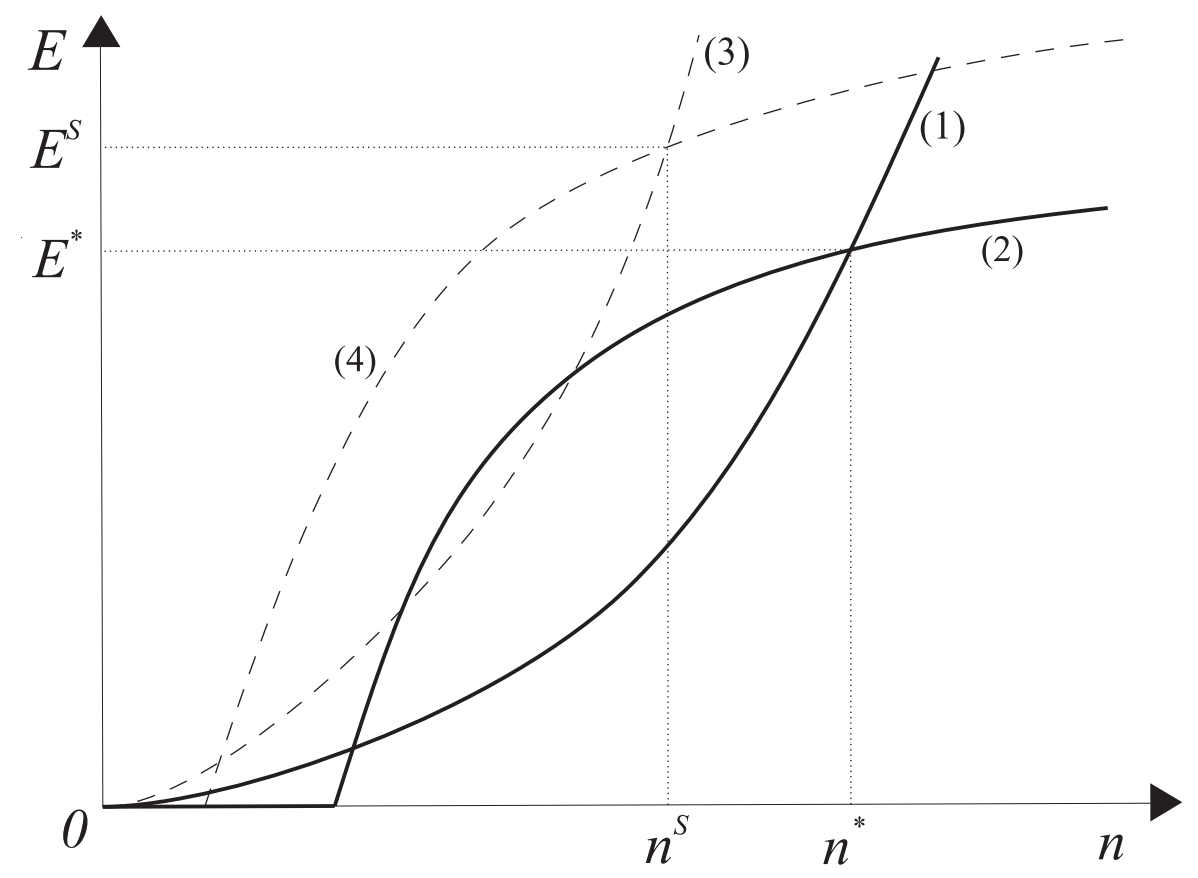

Figure 1: Equilibrium conditions (bold) and optimality conditions (dashed).

The planner's objective function is not globally concave. An interior local maximum satisfies the first-order conditions

$$
\begin{aligned}
& \frac{E t}{4 n^{2}}=F \\
& C E=A-b-\frac{t}{4 n} .
\end{aligned}
$$

As shown in Figure 1, these two conditions intersect twice, but only the larger intersection is the maximum (the other is a saddle point of the objective function). Denote the social optimum by $\left(n^{S}, E^{S}\right)$. The optimal-entry condition (3) is left of the free-entry condition (1): conditional on $E$, there is too much entry in this model which is due to the well-known business-stealing effect in the Salop (1979) model. On the other hand, the optimal-education condition (4) is above the educationchoice condition (2). Conditional on $n$, too few workers decide to obtain education. This is because workers do not internalize the positive externality of their education decision on technology firms' profits. The results that workers invest too little and 
that firms invest too much $^{5}$ are not only true conditional on investment on the other market side, but even unconditional:

Proposition 1 In an equilibrium with positive investment, education is too low and entry of technology firms is excessive, i.e. $E^{*}<E^{S}$ and $n^{*}>n^{S}$.

Proof: Substitution of (3) into (4) shows that $E^{S}$ satisfies

$$
C E=A-b-\frac{1}{2} \sqrt{\frac{F t}{E}} .
$$

On the other hand, substitution of (1) into (2) implies that $E^{*}$ solves

$$
C E=A-b-\frac{5}{4} \sqrt{\frac{F t}{E}} .
$$

Because the right-hand side in (6) is smaller than in (5) and because $E^{S}$ and $E^{*}$ are the larger of the two positive roots of (5) and (6), it follows that $E^{*}<E^{S}$.

To prove the second claim, substitution of (4) into (3) and of (2) into (1) show that $n^{S}$ solves

$$
G^{S}(n)=A-b-\frac{t}{4 n}-\frac{C F 4 n^{2}}{t}=0
$$

and that $n^{*}$ solves

$$
G^{*}(n)=A-b-\frac{5 t}{4 n}-\frac{C F n^{2}}{t}=0 .
$$

Both $G^{S}$ and $G^{*}$ are hump-shaped functions which converge to $-\infty$ when $n \rightarrow 0$ or $n \rightarrow \infty$. Moreover $G^{S}(n)<G^{*}(n)$ iff $n>n_{0}=\left[t^{2} /(3 C F)\right]^{1 / 3}$ and $G^{*}$ has a local maximum at $n_{1}=\left[5 t^{2} /(8 C F)\right]^{1 / 3}$. On the other hand, $G^{*}\left(n_{1}\right) \geq 0$ is necessary for an equilibrium with positive investment, and then $n_{1} \leq n^{*}$ because $n^{*}$ is the larger of the two positive solutions of $G^{*}(n)=0$. Because of $n_{1}>n_{0}$, it follows that $n^{*} \geq n_{1}>n_{0}$ and therefore $G^{S}\left(n^{*}\right)<G^{*}\left(n^{*}\right)=0$ which implies that $n^{S}<n^{*}$.

\section{Human capital externalities}

In the light of Proposition 1, it is obvious that an appropriate combination of an education subsidy with a profit tax (accompanied by a lump-sum tax/transfer)

\footnotetext{
${ }^{5}$ In a related model, Kaas and Madden (2008) show that firms invest too little at the intensive margin due to a holdup-type argument.
} 
can implement the first-best solution. What is more, welfare can be raised by an education subsidy alone, although the consequence is that even more than $n^{*}>n^{S}$ technology firms enter the market. To see this, solve the free-entry condition (1) for $n(E)$ and substitute it into the welfare function to obtain

$$
W(n(E), E)=M b+E\left[A-b-\frac{5}{4} \sqrt{\frac{F t}{E}}\right]-\frac{C E^{2}}{2} .
$$

This term is increasing at $E=E^{*}$. The intuition is as follows: with more humancapital investment more firms enter the market, but since firms make zero profits, the net effect on firms' surplus is nil. The worker surplus must go up, however, since the loss of an increase in $E$ from $E^{*}$ is second-order whilst the gain from an increase in $n$ is first-order: the skilled wage goes up due to fiercer wage competition between technology firms.

This model, as Acemoglu (1996), exhibits a pecuniary externality of human capital investment. When more workers invest in human capital, the skilled wage increases because more technology firms enter who compete more intensively for skilled workers. Obviously, since the low-skill wage is fixed at $b$, the skill premium also increases in response to an expansion of educational attainment. In that respect, the model also exhibits similarities with Acemoglu (2003) who argues that the skill premium increases in response to an increase in the supply of skills because skill-biased technical change raises the relative wage of skilled labor. In this paper, it is not more productive technology that raises wages but it is more intense competition between technology firms. In fact, if the labor market was perfectly competitive, the skill premium would be flat at $A-b$, and also the pecuniary externality disappears. To sum up:

Proposition 2 An increase of education (induced, for example, by an education subsidy) raises the skilled wage and the skill premium. Welfare also increases in $E$ if $E>E^{*}$ is not too large. 


\section{Conclusion}

This paper has identified another mechanism by which social increasing returns to human capital arise due to a pecuniary externality. As in Acemoglu's (1996) model, more education triggers more investment in technology. In contrast to his model, however, productivity of skilled workers does not go up. Instead the wage increase is the result of fiercer competition between technology firms.

\section{References}

Acemoglu, D. (1996): "A Microfoundation for Social Increasing Returns in Human Capital Accumulation," Quarterly Journal of Economics, 111, 779-804.

(2003): "Cross-Country Inequality Trends," The Economic Journal, 113, $121-149$.

Azariadis, C., And A. Drazen (1990): "Threshold Externalities in Economic Development," Quarterly Journal of Economics, 105, 501-526.

Bhaskar, V., and T. To (1999): "Minimum Wages for Ronald McDonald Monopsonies: A Theory of Monopsonistic Competition," The Economic Journal, 109, 190-203.

KaAs, L., And P. Madden (2008): "Holdup in Oligopsonistic Labour Markets a New Role for the Minimum Wage," Labour Economics, 15, 334-349.

LucAs, R. (1988): "On the Mechanics of Economic Development," Journal of Monetary Economics, 22, 3-42.

SAlop, S. (1979): "Monopolistic Competition with Outside Goods," Bell Journal of Economics, 10, 141-156. 